\title{
Faktor Risiko Hipertensi pada Penderita Diabetes Mellitus Tipe 2
}

\author{
Sara Sonnya Ayutthaya ${ }^{1}$, Nurhayati Adnan ${ }^{2}$ \\ 1,2Fakultas Kesehatan Masyarakat, Universitas Indonesia \\ Jl. Lingkar Kampus Raya Universitas Indonesia, Kota Depok, Jawa Barat, 16424 \\ E-mail: 'thaya70.na@gmail.com, 2nprihart@gmail.com
}

\begin{abstract}
Abstrak
Penyakit komorbid Diabetes Melitus (DM) yang umum dan paling sering adalah hipertensi. DM dan hipertensi terdapat secara bersamaan pada $40 \%-60 \%$ penderita DM tipe 2. Tujuan penelitian ini adalah untuk mengetahui unmodifiable factors dan modifiable factors pada penderita DM tipe 2 sebagai faktor risiko hipertensi. Desain penelitian ini adalah cross sectional. Sampel penelitian adalah pasien DM tipe 2 yang berobat di poli penyakit dalam RSUD dr. Chasbullah Abdulmadjid Kota Bekasi pada tanggal 30 September-19 Oktober 2019 dengan total sampel sebanyak 292 responden. Unmodifiable factors meliputi gender, umur, pendidikan, status perkawinan, lama menderita DM, hereditas DM, hereditas hipertensi dan golongan darah. Sedangkan modifiable factors terdiri dari indeks massa tubuh, pekerjaan, aktifitas fisik dan merokok. Hipertensi adalah keadaan tekanan darah sistolik $\geq 140 \mathrm{~mm} \mathrm{Hg}$ dan/atau tekanan darah diastolik $\geq 90 \mathrm{~mm} \mathrm{Hg}$. Analisis data dengan Cox regression menggunakan Stata versi I5. Persentase hipertensi pada penderita DM tipe 2 adalah 46,57\%. Dari analisis multivariat faktor risiko hipertensi yang signifikan untuk unmodifiable factors adalah faktor umur $>50$ tahun $(P v=0,02 ; P R=1,93)$ dan kelompok dengan hereditas DM yang berasal dari kakek/nenek $(P v=0,04 ; P R=1,86)$ dan orang tua $(P v=0,04 ; P R=1,54)$. Sedangkan dari modifiable factors, Indeks Massa Tubuh berat badan lebih $(P v=0,0 I ; P R=I, 8 I)$ dan obesitas $(P v=0,02 ; P R=I, 8 I)$, merupakan faktor risiko hipertensi yang signifikan. Disarankan agar terhadap pasien DM tipe 2 terutama bila disertai dengan berat badan berlebih atupun obesitas perlu diberikan informasi lengkap tentang faktor risiko hipertensi.
\end{abstract}

Kata Kunci : DM tipe 2, hipertensi, unmodifiable factors, modifiable factors

\begin{abstract}
The most common Diabetes Mellitus (DM) comorbid disease is hypertension. DM and hypertension are present simultaneously in $40 \%-60 \%$ of people with type 2 diabetes. The purpose of this study is to know unmodifiable factors and modifiable factors of type $2 \mathrm{DM}$ patients as risk factors for hypertension, The design of this study was cross sectional. The sample of study was type 2 DM patients those seeking treatment at Department of Internal Medicine-dr Chasbullah Abdulmadjid Hospital-Bekasi on September 30-October 19, 2019 with a total of 292 respondents. Unmodifiable factors include gender, age, education, marital status, duration of DM, heredity of DM, heredity of hypertension and $A B O$ blood group. While modifiable factors consist of body mass index, occupation, physical activity and smoking. Hypertension is a state of systolic blood pressure $\geq 140 \mathrm{~mm} \mathrm{Hg}$ and lor diastolic blood pressure $\geq 90 \mathrm{~mm} \mathrm{Hg}$, Data were analysed with Cox regression using Stata versi 15. The precentage of hypertension in patients with type 2 DM was $46.57 \%$. Multivariate analysis revealed that the significant hypertension risk factors for unmodifiable factors are age $>50$ years $(P v=0,02 ; P R=1,93)$ and $D M$ heredity from grandfather/grandmother $(P v=0,04 ; P R=1,86)$ and parents $(P v=0,04 ; P R=1,54)$. While from modifiable factors, Body Mass Index overweight $(P v=0,0 I ; P R=I, 8 I)$ and obesity $(P v=0,02 ; P R=I, 8 I)$ were the significant risk factors for hypertension. It is recommended that patients of type 2 diabetes especially when accompanied by overweight or obesity need to be given complete information about risk factors for hypertension
\end{abstract}

Keywords: Type 2 DM, hypertension, unmodifiable factors, modifiable factors. 


\section{Pendahuluan}

Menurut World Health Rankings, angka kematian akibat hipertensi di Indonesia adalah 14,41 per 100.000 penduduk dan berada di peringkat ke-87 dari 183 negara. ${ }^{1}$ Sedangkan angka kematian akibat DM di Indonesia adalah 53,33 per 100.000 penduduk berada di zona merah (high) di urutan 32 dari 183 negara. $^{2} \quad$ Data Riskesdas 2018 menunjukkan ada peningkatan kasus hipertensi sejak tahun 2013, yaitu dari $25,8 \%$ menjadi $34,1 \%$, serta peningkatan kasus Diabetes Melitus (DM) tipe 2 dari 6,9\% menjadi $8,5 \% .^{3}$ Data Kementerian Kesehatan menyatakan bahwa sepanjang paruh pertama tahun 2018 hipertensi menduduki urutan pertama dalam daftar penyakit tidak menular dengan jumlah 185.857 kasus. Jumlah ini merupakan 4 kali lipat lebih banyak dari penyakit DM yang menduduki peringkat kedua. ${ }^{4}$

Pada penderita DM, kadar glukosa darah meningkat (hiperglikemia) sehingga terjadi resistensi cairan intravaskular yang berakibat pada peningkatan volume cairan tubuh serta diikuti dengan kerusakan sistem vaskular yang menyebabkan peningkatan resistensi arteri perifer. Kedua keadaan ini yang menjadi dasar terjadinya hipertensi. Dalam perkembangan yang lebih lama, keadaan hipertensi yang diikuti dengan kerusakan vaskular lebih lanjut, akan menimbulkan komplikasi Cardiovascular Diseases (CVD) dan Chronic Kidney Diseases (CKD) yang merupakan penyebab utama kematian. ${ }^{5}$

Penelitian Tzanakaki et al., menyatakan bahwa penyebab utama CKD adalah diabetes $(19,5 \%){ }^{6}$ Tindakan upaya penanganan CKD tahap lanjut adalah hemodialisis. Menurut Indonesian Renal Registry (IRR) tahun 2018, pasien CKD yang menjalani hemodialisis terbanyak disebabkan hipertensi (36\%) diikuti dengan DM tipe $2(28 \%)$ dan penyebab kematian terbanyak pada pasien hemodialisis adalah kardiovaskular $(42 \%) .^{7} \quad$ Penelitian Umami et al.,menemukan bahwa 3 bulan setelah hemodialisis insidens mortalitas adalah sebesar $31,7 \%{ }^{8}$

Penelitian lain menunjukan bahwa lebih dari $50 \%$ pasien DM menderita hipertensi dan secara signifikan hipertensi ini mempercepat timbulnya komplikasi DM terhadap penyakit mikro dan makrovaskular yang meliputi Cardiovascular Diseases (CVD) dan Chronic Kidney Diseases (CKD). DM dengan komorbid hipertensi akan meningkatkan risiko $C V D$ dan $C K D{ }^{9}$ Penelitian yang dilaksanakan di Diabetes Clinic and Medical Wards of the University College Hospital, Ibadan-Nigeria yang melibatkan 83 wanita $(66,94 \%)$ dan 41 pria $(33,06 \%)$ dengan umur rata-rata responden 61,1 tahun $(\mathrm{SD}=11,1)$ menunjukan bahwa penderita DM yang disertai dengan hipertensi adalah 49,6\% dan penderita hipertensi yang disertai dengan DM $43 \%$. Kedua keadaan ini akan meningkatkan risiko CVD dan CKD secara signifikan. ${ }^{10}$

Penelitian case control pada 10 puskesmas di Jeddah menyatakan bahwa risiko penderita DM mengalami hipertensi 3,58 kali lebih tinggi secara signifikan dibandingkan dengan bukan penderita DM. ${ }^{11}$ Penelitian yang dilakukan di Prince Hashem bin Abdulla II Hospital di Aqaba, Yordania menunjukkan bahwa faktor risiko hipertensi pada penderita DM tipe 2 adalah usia di atas 65 tahun, lama menderita DM lebih dari 10 tahun, dan IMT kategori overweight dan obese. ${ }^{12}$

Penelitian di Ethiopia terhadap 140 penderita DM tipe 2 menemukan bahwa faktor risiko terjadinya hipertensi pada penderita DM adalah gender pria, usia di atas 50 tahun, marital status (menikah), tingkat pendidikan (perguruan tinggi), dan pensiunan. ${ }^{13}$ Bagi negara-negara di Asia, umur yang muda saat menderita DM serta lamanya menderita DM merupakan risiko tinggi untuk mengalami komplikasi kardiorenal yang menjadi sebab utama mortalitas. Oleh karena itu, upaya pencegahan dan pengendalian harus merupakan prioritas utama program kesehatan masyarakat. ${ }^{14}$ Dengan kondisi 
hipertensi sebagai peringkat pertama dan DM di peringkat kedua pada penyakit tidak menular serta hipertensi yang menjadi komorbid DM, menjadikan kedua penyakit ini menjadi masalah kesehatan masyarakat. $^{4}$

Data Riskesdas 2018 memperlihatkan bahwa prevalensi DM di Jawa Barat adalah 1,3\% berada pada urutan ke-19 dari 34 provinsi. ${ }^{15}$ Menurut Badan Pusat Statistik Kota Bekasi, pada tahun 2017 DM dan hipertensi termasuk dalam daftar 10 penyakit terbanyak. DM berada pada urutan ke-3 (50.462 kasus) dan hipertensi pada urutan ke-4 (45.704 kasus). ${ }^{16}$ Pada tahun 2016, prevalensi hipertensi di Kota Bekasi sebesar 1\% berada pada urutan ke 19 dari 27 kabupaten dan kota di Jawa Barat. ${ }^{17}$ Dari data kunjungan pasien rawat jalan poli penyakit dalam RSUD dr. Chasbullah Abdulmadjid Kota Bekasi tahun 2018, DM tipe 2 dan hipertensi masuk ke dalam 10 besar penyakit terbanyak dengan DM tipe 2 pada urutan pertama sebanyak 8459 kasus dan hipertensi pada urutan ke 2 dengan 5138 kasus. ${ }^{18}$ Berdasarkan uraian diatas, penelitian ini bermaksud untuk mengetahui faktor risiko hipertensi pada penderita DM tipe 2 di kota Bekasi untuk dipergunakan sebagai dasar menyusun program pencegahan komplikasi DM tipe 2.

\section{Metode}

Penelitian ini menggunakan desain studi cross sectional, yaitu untuk mengetahui prevalensi suatu status kesehatan atau penyakit serta faktor yang terkait secara bersamaan dalam satu waktu tertentu. ${ }^{19}$ Populasi penelitian ini yaitu pasien dewasa rawat jalan dengan DM tipe 2 di poli penyakit dalam RSUD dr. Chasbullah Abdulmadjid Kota Bekasi pada tanggal 30 September-19 Oktober 2019. Kriteria inklusi penelitian ini adalah pasien rawat jalan dengan DM di poli penyakit dalam RSUD dr. Chasbullah Abdulmadjid Kota Bekasi dan usia dewasa ( $\geq 18$ tahun). Sedangkan kriteria eksklusi yaitu pasien
DM tipe 1, pasien yang terlebih dahulu didiagnosis hipertensi sebelum DM, disertai komplikasi kardiorenal, dan tidak bersedia ikut dalam penelitian. Pengambilan sampel diambil secara consecutive sampling, yaitu cara pengambilan sampel yang dilakukan dengan cara memilih sampel yang memenuhi kriteria penelitian sampai kurun waktu tertentu sehingga jumah sampel terpenuhi dengan total sampel sebanyak 292 responden. $^{20}$

Data dalam penelitian ini adalah data primer yang diperoleh melalui pengukuran dan kuesioner. Variabel penelitian meliputi unmodifiable factors (umur, gender, status perkawinan, pendidikan terakhir, lama menderita DM, hereditas DM, hereditas hipertensi, golongan darah) dan modifiable factors (IMT, aktivitas fisik, pekerjaan, merokok).

Data pengukuran meliputi tekanan darah dan IMT (tinggi badan dan berat badan). Pengukuran tekanan darah dilakukan dengan menggunakan tensimeter digital "Omron" seri HEM 7120. Responden dipastikan tidak melakukan kegiatan olahraga, merokok, dan makan 30 menit sebelum pengukuran. Responden dibiarkan duduk/istirahat 5-15 menit dalam ruangan yang tenang. Posisi kaki responden tidak menyilang dan kedua telapak kaki menyentuh lantai. Lengan kanan di atas meja dengan telapak tangan terbuka ke atas. Lengan baju kanan disingsingkan dalam keadaan longgar. Manset yang sesuai pada lengan kanan responden dipasang dengan posisi kira-kira 1-2 cm di atas siku. Kemudian tekan tombol "start", maka pressure cuff akan naik sampai tingkat tertentu dan kemudian turun secara otomatis. Hasil yang tertera pada layar dicatat sebagai tekanan sistolik dan diastolik. Setelah istirahat 5 menit dilakukan pengukuran kedua. Bila terjadi perbedaan, nilai yang dipergunakan adalah nilai rata-rata. Apabila kunjungan pasien adalah kunjungan pertama, dilakukan pengukuran pada kedua lengan yaitu kiri dan kanan. Data yang dipergunakan adalah 
pengukuran tertinggi. Selanjutnya pengukuran kedua, dilakukan pada lengan yang sama. ${ }^{21}$ Data IMT diperoleh dengan cara mengukur tinggi badan dan berat badan menggunakan microtoir ZT 150. Angka perbandingan berat badan $(\mathrm{kg})$ dengan kuadrat tinggi badan $\left[\mathrm{BB}(\mathrm{kg}) / \mathrm{TB}^{2}\right.$ (m)] merupakan data IMT. IMT diklasifikasi menjadi kurus $(<18,5)$, normal (18,5-24,99), berat badan lebih $(25-29,99)$, dan obesitas $(\geq 30){ }^{22}$

Variabel selain tekanan darah dan IMT diperoleh melalui kuesioner. Informasi aktifitas fisik menggunakan International Physical Activity Questionnaire versi Short-Form (IPAQSF) dengan bantuan IPAQ automatic report untuk mengklasifikasi aktifitas fisik responden. Hasil kuesioner aktifitas fisik akan diklasifikasi menjadi kurang (tidak melakukan aktifitas fisik sedang atau berat), sedang ( $\geq 3$ hari melakukan aktifitas berat minimal 20 menit per hari, atau $\geq 5$ hari melakukan aktifitas sedang dan/atau berjalan minimal 30 menit per hari, atau $\geq 5$ hari melakukan kombinasi berjalan dengan aktifitas sedang atau berat dan total aktifitas fisik minimal 600 METmenit/minggu), dan berat $(\geq 3$ hari melakukan aktifitas berat dengan minimal total aktifitas fisik 1500 METmenit/minggu, atau $\geq 7$ hari melakukan kombinasi berjalan, aktifitas sedang atau berat dengan minimal total aktifitas fisik 3000 MET-menit/minggu). ${ }^{23}$ Informasi kebiasaan merokok juga diperoleh melalui kuesioner lalu diklasifikasi menggunakan klasifikasi CDC (2017) yaitu tidak pernah merokok), mantan perokok (merokok paling sedikit 100 batang, tetapi saat interview pasien sudah tidak merokok), dan masih merokok (merokok >100 batang dan masih merokok sampai saat diwawancara). ${ }^{24}$

Pengolahan dan analisis data menggunakan perangkat lunak program Stata versi 15.0. Analisis data dilakukan secara univariat (untuk mengetahui distribusi, frekuensi dan proporsi hipertensi menurut unmodifiable factors dan modifiable factors serta mengetahui karakteristik responden) dan bivariat (untuk mengetahui besaran faktor risiko hipertensi yang ditunjukkan dengan nilai prevalence ratio/PR pada unmodifiable factors dan modifiable factors). Pada tahap akhir dilakukan analisis multivariat untuk mengetahui faktor risiko hipertensi yang dominan. Besar asosiasi antara faktor risiko dengan kejadian hipertensi menggunakan Prevalence Ratio (PR) yang didapatkan dari analisis cox regression yang dimodifikasi dengan menetapkan waktu follow-up yang konstan atau sama pada semua individu baik pada kelompok terpapar maupun tidak terpapar. Nilai Hazard Ratio diasumsikan setara dengan Prevalence Ratio pada studi crosssectional. ${ }^{25}$ Secara stepwise, faktor risiko dengan nilai $\mathrm{p}>0,05$ akan dikeluarkan dari model secara bertahap dimulai dari $p$ value yang paling besar dan akan dilihat faktor risiko yang layak untuk dipertahankan serta berpengaruh terhadap kejadian hipertensi.

Hasil

Tabel 1 memperlihatkan bahwa mayoritas responden adalah wanita $(59,59 \%)$ dan kelompok umur $>50$ tahun $(81,51 \%)$. Tingkat pendidikan responden terbanyak adalah SMP $(45,21 \%)$ dan hanya sedikit yang berpendidikan perguruan tinggi $(15,75 \%)$. Sebagian besar responden berstatus menikah $(95,21 \%)$. Secara keseluruhan $76,71 \%$ responden menderita $\mathrm{DM} \leq 10$ tahun. Dari penelitian ini diketahui bahwa responden dengan hereditas DM didominasi oleh kelompok yang memiliki hereditas DM $(53,08 \%)$ dan paling banyak dari kelompok orangtua $(28,77 \%)$. Pada variabel hereditas hipertensi, proporsi terbesar adalah yang tidak memiliki hereditas hipertensi $(53,42 \%)$. Dari kelompok yang memiliki hereditas hipertensi, proporsi terbesar adalah kelompok hereditas hipertensi dari orangtua $(35,62 \%)$. Golongan darah yang paling banyak adalah golongan darah $\mathrm{O}$ dan yang paling sedikit golongan darah $\mathrm{A}$ 
$(35,96 \%$ vs $17,80 \%)$. Terbanyak IMT responden adalah normal $(41,10 \%)$ dan yang paling sedikit kelompok dengan IMT kurus $(5,14 \%)$. Umumnya status responden adalah tidak bekerja $(74,66 \%)$. Mayoritas, responden melakukan aktifitas fisik dengan kategori kurang $(58,22 \%)$ dan hanya sedikit yang melakukan aktifitas kategori berat $(6,51 \%)$. Pada umumnya responden tidak merokok $(59,93 \%)$ dan hanya $10,96 \%$ yang masih merokok sampai saat penelitian.

Dari tabel 2 diketahui bahwa dari 292 penderita DM tipe 2 sejumlah 136 responden menderita hipertensi $(46.57 \%)$ dengan perbandingan gender pria terhadap wanita 1:1.47. Dibandingkan dengan pria, risiko wanita DM menderita hipertensi 1.33 kali lebih tinggi secara tidak signifikan $(95 \% \mathrm{CI}=0.93-1.89 ;$ p value $=$ 0.12). Responden yang menderita hipertensi paling sedikit pada kelompok umur $\leq 50$ tahun (25.93\%). Dibandingkan dengan kelompok umur $\leq 50$ tahun, risiko kelompok umur > 50 tahun menderita hipertensi 1.98 kali lebih tinggi secara signifikan $(95 \% \mathrm{CI}=1.14-3.44 ; \quad p$ value $=$ 0.02). Pada variabel pendidikan, proporsi

Tabel 1. Distribusi Karakteristik Responden Menurut Faktor Risiko

\begin{tabular}{|c|c|c|c|}
\hline Variabel & Kategori & $\mathbf{n}$ & $\%$ \\
\hline \multicolumn{4}{|l|}{ Unmodifiable factors } \\
\hline \multirow{2}{*}{ Gender } & Pria & 118 & 40,41 \\
\hline & Wanita & 174 & 59,59 \\
\hline \multirow[t]{2}{*}{ Umur (tahun) } & $\leq 50$ & 54 & 18,49 \\
\hline & $>50$ & 238 & 81,51 \\
\hline \multirow[t]{3}{*}{ Pendidikan } & $\leq$ SMP & 132 & 45,21 \\
\hline & SMA & 114 & 39,04 \\
\hline & PT & 46 & 15,75 \\
\hline \multirow[t]{2}{*}{ Status Perkawinan } & Menikah & 278 & 95,21 \\
\hline & Cerai & 14 & 4,79 \\
\hline \multirow[t]{2}{*}{ Lama menderita DM (tahun) } & $\leq 10$ & 224 & 76,71 \\
\hline & $>10$ & 68 & 23,29 \\
\hline \multirow[t]{4}{*}{ Hereditas DM } & Tidak ada & 137 & 46,92 \\
\hline & Kakek/nenek & 20 & 6,85 \\
\hline & Orang tua & 84 & 28,77 \\
\hline & Saudara kandung & 51 & 17,46 \\
\hline \multirow[t]{4}{*}{ Hereditas Hipertensi } & Tidak ada & 156 & 53,42 \\
\hline & Kakek/nenek & 12 & 4,11 \\
\hline & Orang tua & 104 & 35,62 \\
\hline & Saudara kandung & 20 & 6,85 \\
\hline \multirow[t]{4}{*}{ Golongan Darah } & A & 52 & 17,8 \\
\hline & B & 80 & 27,4 \\
\hline & $\mathrm{AB}$ & 55 & 18,84 \\
\hline & $\mathrm{O}$ & 105 & 35,96 \\
\hline \multicolumn{4}{|l|}{ Modifiable factors } \\
\hline \multirow[t]{4}{*}{ Indeks Masa Tubuh (IMT) } & Kurus & 15 & 5,14 \\
\hline & Normal & 120 & 41,1 \\
\hline & Berat badan lebih & 103 & 35,27 \\
\hline & Obesitas & 54 & 18,49 \\
\hline \multirow[t]{2}{*}{ Pekerjaan } & Bekerja & 74 & 25,34 \\
\hline & Tidak bekerja & 218 & 76,66 \\
\hline \multirow[t]{3}{*}{ Aktifitas Fisik } & Kurang & 170 & 58,22 \\
\hline & Sedang & 103 & 35,27 \\
\hline & Berat & 19 & 6,51 \\
\hline \multirow[t]{3}{*}{ Merokok } & Tidak pernah & 175 & 59,93 \\
\hline & Mantan perokok & 85 & 29,11 \\
\hline & Masih merokok & 32 & 10,96 \\
\hline
\end{tabular}


terkecil hipertensi ada pada kelompok berpendidikan SMA (44.74\%) dan tertinggi pada perguruan tinggi (50\%). Dibandingkan dengan kelompok SMA, risiko menderita hipertensi pada kelompok berpendidikan $\leq$ SMP dan perguruan tinggi tidak signifikan $(\mathrm{PR}=1.05$ vs $1.12 ; 95 \%$ $\mathrm{CI}=0.72-1.52$ vs $0.68-1.83 ; p$ value $=0.80$ vs 0.66$)$.

Dalam penelitian ini diketahui bahwa proporsi hipertensi yang paling sedikit adalah pada kelompok menikah (45.68\%). Risiko hipertensi pada kelompok bercerai 1.41 kali lebih tinggi dibandingkan dengan kelompok menikah secara tidak signifikan (95\% CI $=0.71-2.77 ; p$ value $=0.32)$. Proporsi hipertensi kelompok lama DM $\leq$ 10 tahun adalah $44.64 \%$. Risiko hipertensi responden yang menderita $\mathrm{DM}>10$ tahun dibandingkan dengan kelompok yang menderita $\mathrm{DM} \leq 10$ tahun, adalah $1.19 \mathrm{kali}$ lebih tinggi secara tidak signifikan $(95 \%$ $\mathrm{CI}=0.81-1.74 ; \quad \mathrm{p}$ value $=0.38) . \quad$ Pada hereditas DM, proporsi hipertensi paling sedikit berasal dari kelompok yang tidak memiliki hereditas DM (35.77\%). Risiko hipertensi pada kelompok yang memiliki hereditas DM berasal dari kakek/nenek dan saudara kandung masing-masing 1.82 dan 1.53 kali lebih tinggi tetapi tidak signifikan dibandingkan kelompok yang tidak memiliki hereditas DM $(95 \% \mathrm{CI}=0.98$ 3.34 vs $0.96-2.44 ; p$ value $=0.056$ vs 0.07 ). Sedangkan pada kelompok dengan hereditas DM yang berasal dari orang tua berisiko 1.53 kali lebih tinggi menderita hipertensi secara signifikan dibandingkan dengan yang tidak memiliki hereditas DM $(95 \% \mathrm{CI}=1.02-2.28 ; p$ value $=0.03)$. Pada variabel hereditas hipertensi, proporsi hipertensi paling sedikit ada pada kelompok tidak ada hereditas hipertensi (40.83\%). Dibandingkan dengan kelompok tidak ada hereditas hipertensi, risiko hipertensi pada kelompok yang memiliki hereditas hipertensi berasal dari kakek/nenek, orang tua, dan saudara kandung secara berurutan yaitu 1.44, 1.31, dan 1.36 kali lebih tinggi secara tidak signifikan $(95 \% \mathrm{CI}=0.66-3.15$ vs 0.91 -
1.88 vs $0.72-2.58 ; p$ value $=0.35$ vs 0.14 vs 0.34$)$.

Dari variabel golongan darah diketahui bahwa proporsi hipertensi yang paling sedikit adalah golongan darah $\mathrm{AB}$ (40\%). Dibandingkan dengan golongan darah $\mathrm{AB}$, golongan darah $\mathrm{A}, \mathrm{B}$ dan $\mathrm{O}$ mempunyai risiko hipertensi secara tidak signifikan $(\mathrm{PR}=1.06$ vs 1.28 vs $1.21 ; 95 \%$ $\mathrm{CI}=0.59-1.91$ vs $0.76-2.15$ vs $0.74-2.00 ; p$ value $=0.85$ vs 0.35 vs 0.45 ). Pada variabel IMT, kelompok kategori kurus, berat badan lebih dan obesitas, lebih banyak menderita hipertensi. (53.33\% vs $57.28 \%$ vs $61.11 \%$ ). Sedangkan pada kelompok IMT normal, lebih banyak responden dengan non hipertensi (70\%). Dibandingkan dengan IMT normal, kelompok IMT kurus mempunyai risiko hipertensi lebih tinggi secara tidak signifikan $(\mathrm{PR}=1.77 ; 95 \%$ $\mathrm{CI}=0.82-3.82 ; p$ value $=0.14)$, sedangkan pada kelompok dengan IMT berat badan lebih dan obesitas mempunyai risiko hipertensi lebih tinggi secara signifikan $(\mathrm{PR}=1.91$ vs $2.03 ; 95 \% \mathrm{CI}=1.26-2.89$ vs 1.27-3.26; $p$ value $=0.00$ vs 0.00). Dari variabel pekerjaan diketahui bahwa pada kelompok yang tidak bekerja, proporsi hipertensi dan non hipertensi adalah sama (50\%). Sedangkan pada kelompok yang bekerja proporsi hipertensi lebih kecil (36.49\%). Responden yang tidak bekerja mempunyai risiko hipertensi 1.37 kali lebih tinggi secara tidak signifikan dibandingkan dengan responden yang bekerja $(95 \% \mathrm{CI}=0.89-2.08 ; p$ value $=$ $0.14)$. Secara keseluruhan hanya $26.32 \%$ responden penelitian ini yang melakukan aktifitas fisik berat. Dibandingkan dengan kelompok yang melakukan aktifitas fisik berat, kelompok dengan aktifitas fisik kurang dan sedang, mempunyai risiko menderita hipertensi secara tidak signifikan $(\mathrm{PR}=1.74$ vs $1.96 ; 95 \% \mathrm{CI}=$ $0.70-4.30$ vs $0.78-4.89 ; p$ value $=0.23$ vs $0.15)$. Dalam penelitian ini yang paling sedikit menderita hipertensi adalah kelompok yang tidak merokok $(40.57 \%)$ dan proporsi hipertensi yang paling besar adalah pada kelompok yang masih 
Tabel 2. Hubungan antara Unmodifiable dan Modifiable Factors dengan Kejadian Hipertensi pada Pasien DM Tipe 2

\begin{tabular}{|c|c|c|c|c|c|c|c|}
\hline \multirow{3}{*}{ Variabel } & \multirow{3}{*}{ Kategori } & \multicolumn{4}{|c|}{ Status Hipertensi } & \multirow{3}{*}{$\begin{array}{c}\text { PR } \\
(95 \% \mathrm{CI})\end{array}$} & \multirow{3}{*}{ Pvalue } \\
\hline & & \multicolumn{2}{|c|}{ Hipertensi } & \multicolumn{2}{|c|}{$\begin{array}{c}\text { Tidak } \\
\text { Hipertensi }\end{array}$} & & \\
\hline & & $\mathbf{n}$ & $\%$ & $\mathbf{n}$ & $\%$ & & \\
\hline \multicolumn{8}{|l|}{ Unmodifiable factors } \\
\hline \multirow[t]{2}{*}{ Gender } & Pria & 46 & 38,98 & 72 & 61,02 & 1 & \\
\hline & Wanita & 90 & 51,72 & 84 & 48,28 & $1,33(0,93-1,89)$ & 0,12 \\
\hline \multirow[t]{2}{*}{ Umur (tahun) } & $\leq 50$ & 14 & 25,93 & 40 & 74,07 & 1 & \\
\hline & $>50$ & 122 & 51,26 & 116 & 48,74 & $1,98(1,14-3,44)$ & $0,02 *$ \\
\hline \multirow[t]{3}{*}{ Pendidikan } & $\leq \mathrm{SMP}$ & 51 & 44,74 & 63 & 55,26 & 1 & \\
\hline & SMA & 62 & 46,97 & 70 & 53,03 & $1,05(0,72-1,52)$ & 0,80 \\
\hline & PT & 23 & 50 & 23 & 50 & $1,12(0,68-1,83)$ & 0,66 \\
\hline \multirow[t]{2}{*}{ Status Perkawinan } & Menikah & 127 & 45,68 & 151 & 54,32 & 1 & \\
\hline & Cerai & 9 & 64,29 & 5 & 35,71 & $1,41(0,72-2.77)$ & 0,32 \\
\hline \multirow{2}{*}{$\begin{array}{l}\text { Lama menderita DM } \\
\text { (tahun) }\end{array}$} & $\leq 10$ & 100 & 44,64 & 124 & 55,36 & 1 & \\
\hline & $>10$ & 36 & 52,94 & 32 & 47,06 & $1,19(0,81-1,74)$ & 0,38 \\
\hline \multirow[t]{4}{*}{ Hereditas DM } & Tidak ada & 49 & 35,77 & 88 & 64,23 & 1 & \\
\hline & Kakek/nenek & 13 & 65 & 7 & 35 & $1,82(0,98-3,34)$ & 0,056 \\
\hline & Orang tua & 46 & 54,76 & 38 & 45,24 & $1,53(1,02-2,28)$ & $0,03 *$ \\
\hline & Saudara kandung & 28 & 54,9 & 23 & 45,1 & $1,53(0,96-2,44)$ & 0,07 \\
\hline \multirow[t]{4}{*}{ Hereditas Hipertensi } & Tidak ada & 63 & 40,83 & 93 & 59,62 & 1 & \\
\hline & Kakek/nenek & 7 & 58,33 & 5 & 41,67 & $1,44(0,66-3,15)$ & 0,35 \\
\hline & Orang tua & 55 & 52,88 & 49 & 47,12 & $1,31(0,91-1,88)$ & 0,14 \\
\hline & Saudara kandung & 11 & 55 & 9 & 45 & $1,36(0,72-2,58)$ & 0,34 \\
\hline \multirow[t]{4}{*}{ Golongan Darah } & A & 22 & 40 & 33 & 60 & 1 & \\
\hline & B & 22 & 42,31 & 30 & 57,69 & $1,06(0,59-1,91)$ & 0,85 \\
\hline & $\mathrm{AB}$ & 55 & 51,25 & 39 & 48,75 & $1,28(0,76-2,15)$ & 0,35 \\
\hline & $\mathrm{O}$ & 11 & 48,57 & 54 & 51,43 & $1,21(0,74-2,00)$ & 0,45 \\
\hline \multicolumn{8}{|l|}{ Modifiable factors } \\
\hline \multirow{4}{*}{$\begin{array}{l}\text { Indeks Masa Tubuh } \\
\text { (IMT) }\end{array}$} & Normal & 36 & 30 & 84 & 70 & 1 & \\
\hline & Kurus & 8 & 53,33 & 7 & 46,67 & $1,78(0,83-3,82)$ & 0,14 \\
\hline & Berat badan lebih & 59 & 57,28 & 44 & 44 & $1,91(1,26-2,89)$ & $0,00 *$ \\
\hline & Obesitas & 33 & 61,11 & 21 & 21 & $2,04(1,27-3,27)$ & $0,00 *$ \\
\hline \multirow[t]{2}{*}{ Pekerjaan } & Bekerja & 27 & 36,49 & 47 & 63,51 & 1 & \\
\hline & Tidak bekerja & 109 & 50 & 109 & 50 & $1,37(0,90-2,09)$ & 0,14 \\
\hline \multirow[t]{3}{*}{ Aktifitas Fisik } & Berat & 5 & 26,32 & 14 & 73,68 & 1 & \\
\hline & Kurang & 78 & 45,88 & 92 & 54,12 & $1,74(0,70-4,30)$ & 0,23 \\
\hline & Sedang & 53 & 51,46 & 50 & 48,54 & $1,96(0,78-4,89)$ & 0,15 \\
\hline \multirow[t]{3}{*}{ Merokok } & Tidak pernah & 71 & 40,57 & 104 & 59,43 & 1 & \\
\hline & Mantan perokok & 47 & 55,29 & 38 & 44,71 & $1,36(0,94-1,97)$ & 0,10 \\
\hline & Masih merokok & 18 & 56,25 & 14 & 43,75 & $1,39(0,83-2,33)$ & 0,22 \\
\hline
\end{tabular}

Keterangan: *= Bermakna secara statistik pada alpha $(\alpha) 0,05$

merokok (56.25\%). Dibandingkan dengan kelompok tidak pernah merokok, kelompok mantan perokok dan masih merokok berisiko hipertensi lebih tinggi secara tidak signifikan $(\mathrm{PR}=1.36$ vs 1.39 ; $95 \% \mathrm{CI}=0.94-1.97$ vs $0.83-2.33 ; p$ value $=$ 0.10 vs 0.21 ).

Dari hasil analisis bivariat diketahui ada 8 variabel dengan $p$ value $<0,25$ yang secara berurutan adalah aktifitas fisik, pekerjaan, hereditas hipertensi, merokok, gender, umur, IMT dan hereditas DM.
Delapan variabel ini dimasukkan ke dalam analisis multivariat mulai dari urutan PR yang terbesar. Dari setiap hasil analisis, satu per satu variabel yang mempunyai $p$ value terbesar dikeluarkan dengan memperhatikan perubahan nilai PR. Setelah dilakukan analisis secara keseluruhan (tabel 3) diketahui bahwa dari unmodifiable factors, faktor risiko hipertensi yang signifikan pada penderita DM tipe 2 adalah umur $>50$ tahun yaitu 1,93 kali lebih tinggi dibandingkan $\leq 50$ 
Tabel 3. Faktor Prediktor Hipertensi Pada Penderita DM Tipe 2 Berdasarkan Analisis Multivariat

\begin{tabular}{cllc}
\hline \multicolumn{1}{c}{ Variabel } & \multicolumn{1}{c}{ Kategori } & PR (95\% CI) & Pvalue \\
\hline Umur (tahun) & $\leq 50$ & 1 & \\
& $>50$ & $1,93(1,11-3,37)$ & 0,02 \\
Hereditas DM & Tidak ada & 1 & \\
& Kakek/nenek & $1,86(1,01-3,44)$ & 0,04 \\
& Orang tua & $1,54(1,02-2,33)$ & 0,04 \\
& Saudara kandung & $1,40(0,87-2,23)$ & 0,15 \\
IMT & Normal & 1 & \\
& Kurus & $1,55(0,72-3,34)$ & 0,27 \\
& Berat badan lebih & $1,81(1,19-2,74)$ & 0,01 \\
& Obesitas & $1,81(1,12-2,91)$ & 0,02 \\
\hline
\end{tabular}

tahun serta kelompok yang memiliki hereditas DM berasal dari kakek/nenek dan orang tua merupakan faktor risiko hipertensi 1,86 dan 1,54 kali lebih tinggi dibandingkan dengan kelompok yang tidak mempunyai hereditas DM. Pada modifiable factors, faktor risiko hipertensi yang signifikan adalah IMT berat badan lebih serta obesitas yaitu 1.81 dan 1.81 kali lebih tinggi dibandingkan dengan IMT normal.

\section{Pembahasan}

Penelitian ini dimaksudkan untuk mengetahui unmodifiable factors dan modifiable factors apa saja yang merupakan faktor risiko hipertensi pada penderita DM tipe 2. Hasil akhir analisis multivariat menyatakan bahwa dari unmodifiable factors, faktor umur (> 50 tahun) dan faktor hereditas DM (kakek/nenek dan orang tua) merupakan faktor risiko hipertensi yang signifikan. Sedangkan dari modifiable factors, faktor Indeks Massa Tubuh (berat badan lebih dan obesitas) merupakan faktor risiko hipertensi yang signifikan.

Kekuatan penelitian ini didasarkan pada pengambilan sampel yang dilakukan di poli penyakit dalam terhadap pasien dengan diagnosis pasti DM tipe 2 tanpa komplikasi. Disamping itu pengukuran dilakukan dengan alat terstandar seperti tensimeter digital "Omron" seri HEM 7120 serta mengukur tinggi badan dan berat badan menggunakan microtoir ZT 150 sehingga pengukuran dapat dilakukan secara detail. Kelemahan penelitian ini pada variabel aktifitas fisik dan merokok, karena informasi diperoleh berdasarkan informasi langsung dari responden (self reported). Kesalahan informasi pada kelompok hipertensi dan non hipertensi memungkinkan terjadinya non differential misclassification.

Dari analisis bivariat diketahui bahwa risiko kelompok umur $>50$ tahun menderita hipertensi 1,98 kali lebih tinggi secara signifikan $\quad(95 \% \mathrm{CI}=1,13-3,43$; Pvalue $=0,02)$ dibandingkan dengan kelompok umur $\leq 50$ tahun. Hasil akhir analisis multivariat, risiko hipertensi kelompok umur $>50$ tahun menjadi 1,93 secara signifikan $(95 \% \quad \mathrm{CI}=1,11-3,37$; Pvalue $=0,02)$. Hasil ini sejalan dengan penelitian Paul PJ di Puducherry, India dengan desain cross sectional menemukan bahwa dibandingkan dengan kelompok umur $\leq 55$ tahun, risiko hipertensi kelompok > 55 tahun adalah 2,12 kali lebih tinggi secara signifikan (95\% $\mathrm{CI}=1,64-2,74 ; p$ value $=0,008) .{ }^{26}$ Penelitian lain adalah Bharati et al., yang melakukan penelitian di Mahatma Gandhi Medical College and Research Institute terhadap 856 responden terdiri dari $37,4 \%$ pria, mendapatkan bahwa risiko hipertensi pada kelompok umur $>50$ tahun dibandingkan dengan umur $\leq 50$ tahun adalah 2,14 kali lebih tinggi secara signifikan (95\% $\mathrm{CI}=1,72-2,66$; Pvalue $=0,000) .{ }^{27}$ Penelitian Tripathy di India mendapatkan bahwa risiko hipertensi penderita DM yang berumur 45-69 tahun 7 kali dibandingkan dengan kelompok umur 18-44 tahun (95\% $\mathrm{CI}=4,4-11,3) .{ }^{28}$ Dari beberapa penelitian ini diketahui bahwa makin bertambah 
umur makin tinggi risiko menderita hipertensi. Hal ini kemungkinan terkait dengan proses degeneratif terutama pada sistem vaskular (aterosklerosis). Menurut National Heart, Lung, and Blood Institute salah satu faktor risiko aterosklerosis adalah umur. Pada pria yang berumur 45 tahun atau lebih, risiko aterosklereosis akan meningkat. Sedangkan pada wanita setelah umur 55 tahun.

Penelitian ini menunjukkan risiko wanita menderita hipertensi 1,33 kali lebih tinggi dibandingkan pria secara tidak signifikan. Hasil ini sesuai dengan penelitian Balogun dan Salako yang menemukan bahwa wanita lebih banyak menderita hypertensive diabetics dibandingkan pria dengan perbedaan yang tidak signifikan $(61,7 \%$ vs $38,3 \%$, Pvalue $=$ $0,2) .^{10}$

Dari hasil penelitian ini diketahui bahwa variabel pendidikan dan status pernikahan bukan merupakan faktor risiko hipertensi. Hasil ini sejalan dengan penelitian Pereira $\mathrm{M}$, et al., di Porto, Portugal dengan sampel 796 responden dewasa berumur $>18$ tahun (wanita 62,6\%) dibandingkan dengan kelompok yang level pendidikan <4 tahun, kelompok berpendidikan 4-12 tahun dan kelompok berpendidikan $>12$ tahun mempunyai risiko hipertensi $0,76(95 \% \mathrm{CI}=0,52-1,01)$ dan $0,70(95 \% \mathrm{CI}=0,46-1,08)$ secara tidak signifikan. Sedangkan pada variabel status pernikahan, dibandingkan dengan kelompok yang menikah, risiko hipertensi kelompok lainnya (belum menikah, cerai) adalah $0,83(95 \% \mathrm{CI}=0,56-1,22)$ secara tidak signifikan. ${ }^{29}$

Analisis bivariat penelitian di RSUD Bekasi menunjukkan bahwa risiko hipertensi pada hereditas hipertensi adalah 1.31 lebih tinggi secara tidak signifikan. Keadaan ini sesuai dengan penelitian Sande et al., di Gambia terhadap 5.389 responden dewasa yang menemukan bahwa dibandingkan dengan kelompok tanpa hereditas hipertensi, risiko hipertensi pada kelompok dengan hereditas hipertensi sebesar 1.35 kali secara tidak signifikan
$(\mathrm{AOR}=1.35 ; 95 \% \mathrm{CI}=0.61-3.00) .{ }^{30}$

Dari hasil akhir analisis multivariat diketahui bahwa risiko hipertensi yang signifikan adalah kelompok hereditas DM yang berasal dari kakek/nenek $(\mathrm{PR}=1,86$; 95\% CI= 1,01-3,44; Pvalue $=0,04)$ dan orang tua $(\mathrm{PR}=1,54 ; 95 \% \mathrm{CI}=1,02-2,33$; Pvalue $=0,04)$. Hasil penelitian ini lebih rendah dari penelitian Tripathy yang menemukan bahwa risiko hipertensi pada hereditas DM adalah 2 kali lebih tinggi secara signifikan $\quad(95 \% \mathrm{CI}=1,4-2,8$; Pvalue $=0,001){ }^{28}$ Keterkaitan genetik dengan hipertensi dan DM tipe 2, Koo BK et al., melakukan penelitian terhadap sampel DNA 24 orang Korea. Hasil penelitiannya menemukan bahwa polymorphisms Potassium Inwardly Rectifying Channel Subfamily J Member 11 (KCNJ 11) berhubungan secara signifikan terhadap DM tipe 2 dan kejadian hipertensi. ${ }^{31}$ Penelitian Lasram K, et al., terhadap populasi Tunisia dan Arab dengan desain case control (250 responden dengan DM tipe 2 dan 267 responden kontrol) menemukan hubungan yang signifikan antara gen KCNJ 11 varian E23K dengan $\mathrm{DM}$ tipe $2(\mathrm{OR}=1,6 ; 95 \% \mathrm{CI}=1,14-2,27$; $\mathrm{p}=0,007)$. Peran KCNJ 11 terkait dengan DM tipe 2 adalah dengan membuat subunit channel potassium sensitif-ATP (K-ATP). Setiap K-ATP terdiri dari 8 subunit dan 4 subunit diantaranya dihasilkan oleh $\mathrm{KCNJ}$ 11 (Kir6.1, Kir6.2, sulphonylurea receptor 1/SUR1 dan SUR2) dan 4 lainnya oleh ABCC8. Channel K-ATP ditemukan pada sel $\beta$ pancreas yang menghasilkan hormon insulin. K-ATP akan menempel pada dinding sel untuk membuka dan menutup channel sebagai respons terhadap kadar glukosa darah. Apabila kadar glukosa darah tinggi, terjadi penutupan channel dan sel $\beta$ akan melepaskan insulin ke dalam aliran darah sebagai upaya pengendalian kadar glukosa darah. ${ }^{32}$ Zhancheng W et al., melakukan meta analisis terhadap 7 penelitian case control (kasus 7075 responden dan control 5082 responden) menemukan signifikan model KCNJ 11 varian E23K dan KCNMB1 varian E65K 
secara signifikan berhubungan dengan kejadian hipertensi. Akan tetapi mekanisme pengaruhnya yang pasti masih belum jelas. Peningkatan aktifitas channel K-ATP terutama yang berhubungan dengan KCNJ 11 varian E23K, mempunyai dampak langsung terhadap sistem kardiovaskular terutama terhadap kejadian hipertensi. Demikian pula dampaknya terhadap aktivasi sistem saraf simpatis, memainkan peran yang penting pada kejadian hipertensi. ${ }^{33}$

Hasil penelitian ini menunjukkan bahwa kelompok lama menderita DM > 10 tahun lebih berisiko menderita hipertensi dibandingkan dengan yang menderita $\mathrm{DM} \leq 10$ tahun secara tidak signifikan. Hasil ini sesuai dengan penelitian Zoungas $\mathrm{S}$ et al., terhadap 11.140 individu dengan DM tipe 2 dengan 4 klasifikasi lama menderita DM $(\leq 5,>$ $5-10,>10-15$ dan >15 tahun) menemukan bahwa tidak ada hubungan antara lama menderita DM dengan kejadian hipertensi $(p$ value $=0.1562) .{ }^{34}$

Penelitian ini menunjukkan bahwa golongan darah $\mathrm{A}, \mathrm{B}$, dan $\mathrm{O}$ memiliki risiko menderita hipertensi dibandingkan golongan darah AB. Hasil ini sesuai dengan penelitian Chuemere AW et al., di Nigeria dengan desain cross-sectional population-based terhadap 1.620 responden (53.3\% wanita) menemukan bahwa tidak terdapat hubungan yang signifikan antara golongan darah dengan kejadian hipertensi ( $p$ value > 0.05). ${ }^{35}$

Dalam penelitian ini hasil akhir analisis multivariat diketahui bahwa berat badan lebih dan obesitas secara signifikan merupakan faktor risiko hipertensi. Penelitian Berraho et al., di Maroko menyatakan bahwa risiko hipertensi pada kelompok berat badan lebih 1,7 kali lebih tinggi dan obesitas 3 kali lebih tinggi secara signifikan dibandingkan dengan kelompok IMT normal. ${ }^{36}$ Asresahegn $\mathrm{H}$ et $a l$. , meneliti di Ethiopia dan menemukan bahwa dibandingkan dengan IMT normal (IMT < 25), risiko hipertensi pada kelompok IMT $\geq 25$ (berat badan lebih dan obesitas) adalah 2 kali lebih tinggi secara signifikan $(95 \% \mathrm{CI}=1,1-3,5) .{ }^{37}$ Disfungsi jaringan adiposit pada obesitas berperan pada resistensi insulin dan vaskular serta disfungsi sistem saraf simpatis dan reninangiotensin-aldosterone system (RAAS). Keadaan ini akan menyebabkan perubahan pada struktur dan fungsi ginjal termasuk aktivasi intrarenal angiotensin II yang merupakan dasar hipertensi pada obesitas. $^{38}$

Hasil penelitian ini menunjukkan bahwa responden yang tidak bekerja berisiko 1,37 kali menderita hipertensi secara tidak signifikan. Hasil ini sesuai dengan penelitian Cuschieri S et al., yang dilaksankan oleh University of Malta dengan desain cross-sectional terhadap 3.497 responden berumur 18-70 tahun yang menemukan bahwa dibandingkan dengan kelompok yang bekerja, risiko hipertensi pada kelompok yang tidak bekerja tidak signifikan $(\mathrm{AOR}=1,181$; 95\% CI= 0,974-1,432; Pvalue $=0,091) .{ }^{39}$

Pada penelitian ini, kelompok yang melakukan aktifitas fisik ringan dan sedang memiliki risiko hipertensi secara tidak signifikan dibandingkan dengan kelompok aktifitas fisik berat. Hasil ini sesuai dengan penelitian yang dilakukan Asresahegn $\mathrm{H}$ et al., di Jigjiga city of Somali Regional State, Ethiopia terhadap 455 responden berumur 25-65 tahun menemukan bahwa dibandingkan dengan responden yang melakukan physical activity high (berat), risiko hipertensi pada kelompok responden yang melakukan physical activity moderate (sedang) dan low (ringan) adalah lebih rendah secara tidak signifikan $(\mathrm{AOR}=0,7$; $95 \% \mathrm{CI}=0,3-1,5$ vs $\mathrm{AOR}=0,9 ; 95 \% \mathrm{CI}=$ $0,5-2,0)^{37}$

Hasil penelitian ini menunjukkan jika dibandingkan dengan kelompok tidak pernah merokok, pada kelompok mantan perokok dan masih perokok memiliki risiko menderita hipertensi secara tidak signifikan. Hasil penelitian ini sesuai dengan penelitian Xinyi_Wu dan Zhonghua_Wang di Peking University yang menemukan bahwa 
dibandingkan dengan kelompok tidak merokok, risiko hipertensi pada kelompok yang merokok tidak signifikan $(\mathrm{OR}=$ 0,$81 ; 95 \% \quad \mathrm{CI}=0 ; 579-1 ; 133, \quad$ Pvalue $=$ $0,218){ }^{40}$

\section{Kesimpulan}

Dari unmodifiable factors diketahui bahwa faktor umur $>50$ tahun dan kelompok dengan hereditas DM yang berasal dari kakek/nenek dan hereditas DM yang berasal dari orang tua merupakan faktor risiko hipertensi yang signifikan. Dari modifiable factors diketahui bahwa IMT berat badan lebih dan obesitas merupakan faktor risiko hipertensi yang signifikan. Perlu adanya kebijakan pemerintah untuk meningkatkan pelaksanaan kegiatan "CERDIK" $(\mathrm{C}=\mathrm{Cek}$ kesehatan secara berkala, E=Enyahkan asap rokok, $\mathrm{R}=$ Rajin aktivitas fisik, $\mathrm{D}=$ Diet sehat dengan kalori seimbang, I=Istirahat cukup, dan K=Kelola stres) dalam upaya pencegahan risiko hipertensi terutama bagi kelompok umur $>50$ tahun dan atau yang disertai dengan faktor hereditas DM.

\section{Daftar Pustaka}

1. World Health Rankings. Hypertension Death Rate per 100.000; 2017 [updated 2017; cited 2019 Jan 17]. Available from: https:// www. Worldlifeexpectancy.com/ cause-of-death /hypertension/ by-country/

2. World Health Rankings. Diabetes Mellitus Death Rate per 100.000; 2017 [updated 2017; cited 2019 Jan 17]. Available from: https://www.worldlifeexpectancy.com/cause-ofdeath/diabetes-mellitus/by-coun try/

3. Kementerian Kesehatan RI. Potret Sehat Indonesia dari Riskesdas; 2018 [updated 2018; cited 2019 Jan 26]. Available from http://www.depkes.go.id/article/view/18110200 003/potret-sehat-indonesia -dari-riskesdas2018.html

4. Sulaiman M R. Semester I 2018, Hipertensi Jadi Penyakit Paling Banyak Dialami Penduduk RI; 2018 [updated 2018 Jul 6; cited 2019 Jan 17]. Available from https://health.detik.com/beritadetikhealth/ d-4101603/semester-i-2018Hipertensi-jadi-penyakit-paling-banyakdialami-penduduk-ri

5. Ohishi M. Hypertension with diabetes mellitus: physiology and pathology. Hypertens Res. 2018; 41(6): 389-393
6. Tzanakaki E, Boudouri V, Stavropoulou A, Stylianou K, Rovithis M, Zidianakis Z. Causes and complications of chronic kidney disease in patients on dialysis. Health Science Journal. 2014; 8 (3): 343-349

7. Perkumpulan Nefrologi Indonesia (PERNEFRI). 11 ${ }^{\text {th }}$ Report of Indonesian Renal Registry; 2018 [updated 2018; cited 2020 Jan 25]. Available from https://www.indonesian renal registry. org/data/IRR\%202018.pdf

8. Umami V, Lydia A, Nainggolan G, Setiati S. Pengembangan Model Prediksi Mortalitas 3 Bulan Pertama pada Pasien Penyakit Ginjal Kronik yang Menjalani Hemodialisis. Jurnal Penyakit Dalam Indonesia. 2015; 2 (3): 170-182

9. Lastra.G, Syed.S, Kurukulasuriya R, Manrique C, Sowers J R. Type 2 diabetes mellitus and hypertension: An update. Metab Clin North Am. 2014; 43 (1): 103-122

10. Balogun W O, Salako B L. Co-occurrence of Diabetes and Hypertension: Pattern and factors associated with order of diagnosis among Nigerians. Annals of Ibadan Postgraduate Medicine. 2011; 9 (2): 89-93

11. Murad M A, Abdulmageed S S, Iftikhar S R, Khaled S B K. Assessment of the Common Risk Factors Associated with Type 2 Diabetes Mellitus in Jeddah. International Journal of Endocrinology. 2014 Article ID 616145: 1-9

12. Alqudah et al. Prevalence of hypertension among diabetic type 2 patients attending medical clinic at Prince Hashem bin Abdulla II Hospital in Aqaba. Indian Journal of Medical Research and Pharmaceutical Sciences. 2017; 4 (6): 47-54

13. Tadesse K, Amare H, Hailemariam T, Gebremariam T. Prevalence of Hypertension among Patients with Type 2 Diabetes Mellitus and Its Socio Demographic Factors in Nigist Ellen Mohamed Memorial Hospital Hosanna, Southern Ethiopia. Journal of Diabetes and Metabolism. 2018; 9 (4): 1-7

14. Chan et al. Diabetes in Asia: epidemiology, risk factors, and pathophysiology. Journal of the American Medical Association. 2009; 301 (20): 2129-40

15. Infodatin. Hari Diabetes Sedunia. Kementerian Kesehatan Republik Indonesia. 2018

16. Badan Pusat Statistik Kota Bekasi. Kota Bekasi Dalam Angka Bekasi Municipality in Figures. 2018

17. Profil Kesehatan. Dinas Kesehatan Provinsi Jawa Barat. 2016

18. RSUD dr. Chasbullah Abdul Madjid. 10 Besar Penyakit Rawat Jalan (Penyakit Dalam); 2018 [updated 2018; cited 2020 March 30]. Available from http://www.rsudkotabekasi.net/10-besarpenyakit-r-jalan

19. Centers for Disease and Control and Prevention. Analytic epidemiology; 2012 [updated 2012; 
cited 2019 May 31]. Available from https://www.cdc.gov/csels/dsepd/ss1978/lesson1 /section7.html

20. Hidayat A. Metode Penelitian Keperawatan Dan Teknik Analisis Data. Salemba Medika, Jakarta; 2009

21. Riset Kesehatan Dasar. Pedoman Pengukuran dan Pemeriksaan. Departemen Kesehatan RI. 2007

22. Badan Penelitian dan Pengembangan Kesehatan. Riset Kesehatan Dasar. Kementerian Kesehatan RI. 2013

23. International Physical Activity Questionnaire. Guidelines for Data Processing and Analysis of the International Physical Activity Questionnaire (IPAQ) - Short and Long Forms. 2005

24. National Health Interview Survey. Adult tobacco use-glossary; 2017 [updated 2017; cited 2019 May 31]. Available from https://www.cdc.gov/nchs/nhis/tobacco/tobacco _glossary.htm

25. Rothman K J, Greenlad S, Lash T L. Modern epidemiology 3rd, Lippincott Williams \& Wilkins, Philadelphia; 2008

26. Paul P J, Samson R, William A, Akila B , Purty A J, Bazroy J. Prevalence and factors associated with hypertension: a community based crosssectional study among adults in an urban area of Puducherry, South India. Int J Community Med Public Health. 2017; 4 (5): 1620-1626

27. Bharati D R, Nandi $P$, Yamuna $T V$, Lokeshmaran A, Agarwal L, Singh JB, Basu M, Das P,Pal R. Prevalence and Covariates of Undiagnosed Hypertension in the Adult Population of Puducherry, South India. Nepal Journal of Epidemiology. 2012; 2 (2): 191-99

28. Tripathy $\mathbf{J} \mathrm{P}$ et al. Prevalence and determinants of comorbid diabetes and hypertension: Evidence from non communicable disease risk factor STEPS survey, India. Diabetes \& Metabolic Syndrome: Clinical Research \& Reviews. 2017; 11S: S459-S465

29. Pereira M, Lunet N, Paulo C, et al. Incidence of hypertension in a prospective cohort study of adults from Porto, Portugal. BMC Cardiovascular Disorders. 2012; 12 (114): p 1-8

30. Sande M A, Walraven G E, Miligan PJM, et al. Family history: an opportunity for early interventions and improved control of hypertension, obesity and diabetes. Bulletin of the World Health Organization. 2001; 79: p 321-328

31. Koo B K, Cho Y M, Park B L, Cheong H S, Shin H D, Jang H C, Kim S Y, Lee H K, Park K
S. Polymorphisms of KCNJ11 (Kir6.2 gene) are associated with Type 2 diabetes and hypertension in the Korean population. Diabetic Medicine. 2007; 24 (2): p 178-186

32. Lasram K, Halim N B, Hsouna S, Kefi R, Arfa I, Ghazouani W, Jamoussi H, Benrahma H, Kharrat N, Rebai A, Ammar S B, Bahri S, Barakat A, Abid A, Abdelhak S. Evidence for Association of the E23K Variant of KCNJ11 Gene with Type 2 Diabetes in Tunisian Population: Population-Based Study and MetaAnalysis. BioMed Research International vol 2014, Article ID 265274: p 1-9

33. Zhancheng W, Wenhui J, Yun J, Lingli W, Huijun H, Yan S, Jin L. The dominant models of KCNJ11 E23K and KCNMB1 E65K are associated with essential hypertension (EH) in Asian Evidence from a meta-analysis. Medicine. 2019; 98(23): p 1-9

34.Zoungas S, Woodward M, Qiang Li Q et al. Impact of age, age at diagnosis and duration of diabetes on the risk of macrovascular and microvascular complications and death in type 2 diabetes. Diabetologia. 2014;57(12): p 2465-2474

35. Chuemere A W, Olorunfemi O J, Nwogu J U et al. Correlation between Blood group, Hypertension, Obesity, Diabetes, and combination of Prehypertension and PreDiabetes in School Aged Children and Adolescents in Port Harcourt. Journal of Dental and Medical Sciences. 2015; 14(12): p 83-89

36. Berraho M, Achhab Y E, Benslimane A, Rhazi1 K E, Chikri M, Nejjari C. Hypertension and type 2 diabetes: a cross-sectional study in Morocco. Pan African Medical Journal. 2012; 11 (52): 1-9

37. Asresahegn H, Tadesse F, Beyene E. Prevalence and associated factors of hypertension among adults in Ethiopia: a community based cross-sectional study. BMC Research Notes. 2017; 10 (629): 1-8

38. De Marco V D, Aroor A R, Sowers J R. The pathophysiology of hypertension in patients with obesity. Nat Rev Endocrinol 2014; 10 (6): 364-376

39. Cuschieri S, Vasallo J, Calleja N, et al. The Effects of Socioeconomic Determinants on Hypertension in a Cardiometabolic At-Risk European Country. International Journal of Hypertension. 2017; Article ID 7107385: p 1-7

40. Wu X, Wang Z. Role of Socioeconomic Status in Hypertension among Chinese Middle-Aged and Elderly Individuals. International Journal of Hypertension. 2019; Article ID 6956023: p 1-6 